\title{
SETIA BERBUAH PETAKA (IHWAL KUTUK ASTABASU DAN LAHIRNYA BHISMA DALAM CERITA ADIPARWA)
}

\author{
I Nyoman Duana Sutika \\ Program Studi Sastra Bali, Fakultas Ilmu Budaya, Unud
}

\begin{abstract}
The story in which the curse of Astabasu and the birth of Bhisma are narrated is one of the stories in Adiparwa. It is narrated that BagawanWasistha condemned Astabasu (eight basus) for stealing Nandini, his cow. Prabhata, one of the Astabasus, stole the cow for Dyoh, his wife whom he loved so much and who wanted to consume the milk produced by the cow. Astabasu and Goddess Gangga were condemned for the mistake they had made. Goddess Gangga did not mind reducing the curse of Astabasu for which they were supposed to return to where they had come from, the heaven. When the first seven basus were born, they were returned to where they had come from by Goddess Gangga by throwing them away. Bhisma, the reincarnation of the eighth basu was more heavily and longer punished as he had been primarily responsible for the theft. During his life, Bhisma entirely served the Kuru family and strongly promised that he would never be married 'brahmacari' to make his parents happy.
\end{abstract}

Key words: curse, brahmacari, adiparwa

\section{PENDAHULUAN}

Adiparwa adalah parwa pertama dari delapan belas parwa yang lengkapnya disebut Astadasaparwa menjadi Mahabharata. Epos yang di dalamnya mengandung berbagai dongeng, legenda, mitos, falsafah, sejarah dan sebagainya, intinya bermuara pada konflik dua saudara bersepupu, yaitu Kaurawa dan Pandawa yang menjadi ajang peperangan besar Bharatayuda. Epos yang begitu panjang ini di dalamnya menyajikan beberapa peristiwa mengesankan berupa intrik, ambisi, sentimentil tokoh terhadap tokoh lainnya.

Salah satu kisah menarik yang ada dalam cerita Adiparwa adalah lahirnya tokoh Bhisma yang dianggap sebagai tokoh legendaris, karismatik dan menjadi teladan sezamannya. Selebihnya ia juga tokoh mumpuni di dalam menggunakan senjata, sehingga disegani dan ditakuti oleh para ksatria lainnya. Selain sebagai kakek Kaurawa dan Pandawa, ia juga menjadi guru dan panutan bagi anak cucunya. Walaupun demikian dalam beberapa hal tokoh Bhisma dianggap mempunyai kelemahan karena terikat oleh sumpah dirinya yang akan senantiasa menjaga negeri Hastinapura kebanggaannya dalam keadaan apapun sampai pada tetes darah terakhir.

Pada sisi lain kelahiran tokoh Bhisma tidak lepas dari buah kutuk dari bagawan Wasistha terhadap Prabhata (satu di antara Astabasu/ delapan Basu) yang menjelma menjadi Dewabrata atau Bhisma. Bhisma harus lebih lama hidup di dunia dibandingkan dengan saudara basu lainnya. Selain itu Bhisma juga telah terikat oleh sumpah dirinya yang tidak kawin atau brahmacari selama hidupnya. Bagaimanakah seorang tokoh Bhisma bisa lahir dari buah kutuk, dan melakukan sumpah brahmacari?. Prilaku kontradiktif dewi Gangga juga menyisakan pertanyaan, mengapa ia tega membuang tujuh anak kandung hasil perkawinannya dengan Santanu di tengah sungai?. Inilah hal menarik yang diangkat dalam tulisan ini untuk mendapat jawabannya, berangkat dari aksioma kehidupan yang menyebutkan bahwa 
tiada akibat tanpa sebab. Penelusuran akan jawaban ini tersirat dan tersurat melalui deskripsi awal sinopsis berikut.

Alkisah raja Mahabhima menghadap batara Brahma. Ikut pula hadir Dewi Gangga bersama dewa lainnya. Tiba-tiba pakaian dewi Gangga tersingkap angin sehingga semua dewa tertunduk kecuali Mahabhima. Batara Brahma marah karenanya, lalu mengutuk Mahabhima dan dewi Gangga agar turun atau menjelma ke dunia menjadi pasangan suami istri.

Dalam perjalanan turun ke dunia dewi Gangga bertemu dengan Astabasu (sang Dhara, sang Dhrwa, sang Soma, sang Apah, sang Anila, sang Anala, sang Pratyangga dan sang Prabhata) yang kebetulan juga mendapat kutukan dari bagawan Wasistha karena mencuri lembu miliknya. Dewi Gangga berjanji membantu menebus kesalahan Astabasu untuk segera kembali ke sorga tempat asalnya, kecuali sang Prabhata (wasu ke delapan) yang harus tinggal lebih lama di dunia karena menjadi pelaku utama pencurian lembu Nandini milik bagawan Wasistha.

Ketika dewi Gangga turun ke dunia, Mahabhima telah lebih awal menjelma menjadi Santanu, putra maharaja Pratipa. Saatnya kemudian keduanya bertemu dan saling jatuh cinta. Dewi Gangga menerima pinangan Santanu dengan syarat suaminya kelak tidak boleh melarang apapun yang dilakukan dirinya. Apabila ingkar dewi Gangga akan meninggalkan suaminya. Waktunya tiba dewi Gangga melahirkan anak pertama lalu dibuangnya ke sungai. Begitu juga yang terjadi sampai anak yang ke tujuh (jelmaan tujuh wasu) di buangnya di sungai Gangga. Suaminya tidak bisa marah karena teringat dan terikat oleh penjanjiannya. Tetapi saat kelahiran/penjelmaan sang Prabhata, anaknya ke delapan, maharaja Santanu menegur istrinya. Dengan begitu suaminya dianggap telah ingkar janji sehingga dewi Gangga meninggalkan raja Santanu. Sesaat sebelum meninggalkan suaminya dewi Gangga menceritakan ihwal perbuatan dirinya yang tega membuang anak-anaknya ke sungai.

Sebelum turun ke dunia ia berjanji membantu Astabasu untuk segera mengembalikan ke tempat asalnya/tempat para dewa, kecuali sang Prabhata, karena ia melakukan dosa yang lebih besar dari saudara lainnya. Sang Astabasu mempunyai seorang istri yang sangat dicintainya bernama sang Dyoh. Atas permintaan Sang Dyoh sang Prabhata memimpin Astabasu lainnya bermaksud mencuri lembu Nandini milik bagawan Wasistha, karena dengan meminum air susu lembu tersebut dapat membuat awet muda atau tidak mengenal masa tua. Air susu tersebut akan diberikan oleh sang Dyoh kepada temannya Jiwati anak raja Ucimara agar tidak mengalami ketuaan sehingga dapat melanggengkan persahabatannya.

Karena cintanya sang Astabasu kepada istrinya, tanpa berpikir panjang sang Prabhata dibantu ketujuh saudaranya lalu mencuri lembu Nandini milik bagawan Wasistha. Bagawan Wasistha tahu akan hal tersebut lalu mengutuk Astabasu menjelma menjadi manusia. Sang Prabhata yang mendapat hukuman kutuk paling berat, karena menjadi pelaku utama atau pemimpin perbuatan pencurian tersebut. Ia harus lebih lama tinggal di dunia dibandingkan dengan saudaranya yang lain. Demikian dewi Gangga menjelaskan kepada suaminya Santanu bahwa anaknya yang ke delapan inilah jelmaan sang Prabhata, yang lahir bernama Dewabrata.

Beberapa tahun hidup bersama anak semata wayangnya Dewabrata, Santanu merasa kesepian. Suatu ketika maharaja Santanu bercengkrama di tepi sungai Yamuna. Tercium olehnya bau harum semerbak yang berasal dari sang Sayojanagandhi (Gandhawati) putra sang Dasabala. Raja Santanu sangat tertarik dengan kecantikan Gandhawati namun terkendala oleh rasa sayang dirinya terhadap anaknya, ia mengurungkan niatnya melamar Gandhawati. Oleh karena syarat yang diajukan oleh Dasabala bahwa pinangan Santanu akan diterima hanya apabila kelak keturunan Gandawati yang menduduki tahta.

Terpikir oleh syarat yang diajukan oleh Dasabala, Santanu merasa sedih dan urung melamar Gandhawati. Raja Santanu sangat gelisah bahkan tidak bisa tidur memikirkan hal tersebut. Mengetahui keadaan ayahnya seperti itu Dewabrata mendatangi rumah Dasabala. Akhirnya Dewabrata mengetahui penyebab kegelisahan ayahnya 
dan memohon kepada Dasabala agar berkenan mengabulkan keinginan ayahnya. Dasabala mengabulkan permohonan Santanu, dengan syarat kelak anak keturunan hasil perkawinan dengan Gandawatilah yang menduduki tahta kerajaan. Untuk menyenangkan dan menunjukkan rasa bakti Dewabrata terhadap ayahnya saat itu pula ia mengucapkan sumpah untuk melakukan brahmacari, sekaligus mengantar Gandhawati ke hadapan ayahnya. Atas sumpahnya tersebut mulai sejak itu Dewawrata mendapat gelar kehormatan bernama bagawan Bhisma. Santanu merasa kalah kekuatan bhatinya dengan anaknya dan dengan sukarela menyerahkan Aji Swacchandamarana kepada anaknya yakni kekuatan penahan hidup yang menyebabkab Bhisma dapat hidup ratusan tahun lamanya.

\section{METODOLOGI}

Metode merujuk pada perencanaan yang terorganisasi secara terperinci dan logis untuk mendapatkan serangkaian informasi dari proses penelitian terhadap objek. Secara lebih luas metode dianggap sebagai cara-cara, strategi untuk memahami realitas, langkah-langkah sistematis untuk memecahkan rangkaian sebab akibat berikutnya (Ratna, 2006: 34). Tulisan ini menggunakan metode kualitatif, dengan memberikan perhatian pada teks. Fashri (2007: 36-37) mengemukakan bahwa gagasan yang didudukkan sebagai data kualitatif, tidak mendasarkan pada angka-angka, melainkan atas pandangan, pendapat dan pemikiran. Senada dengan Ratna (2006: 46) yang menyebutkan bahwa metode kualitatif pada dasarnya sama dengan metode hermeneutika, memberikan penafsiran dan mencari makna-makna tersembunyi dalam karya.

Bagi Ricoeur (2006:57) hermeneutika adalah teori tentang bekerjanya pemahaman dalam menafsirkan teks. Penafsiran terjadi karena setiap subjek memandang objek melalui horison dan paradigma yang bebeda-beda. Tulisan ini menggunakan analisis deskriptif kualitatif dengan metode interpretasi atau penafsiran.

\section{PEMBAHASAN}

\subsection{Kutuk dan Sumpah Bhisma}

Hukum kausalitas meniscayakan bahwa setiap peristiwa selalu didahului oleh peristiwa lain sebelumnya. Ini telah menjadi dalil kehidupan bahwa tidak ada akibat tanpa sebab. Begitu pula yang terjadi dalam peristiwa kutuk dan sumpah Bhisma niscaya disebabkan oleh perbuatan sebelumnya. Setiap kehidupan juga tidak bisa lepas dari lingkaran karma yang dilakukan pelaku pada hari sebelum dan sesudahnya. Buah perbuatan inilah yang dinikmati oleh setiap pelaku perbuatan, baik di kehidupan hari ini, sebelum dan yang akan datang.

Dalam ajaran Hindu disebut tri semaya, yaitu tiga konsepsi yang berorientasi pada kelangsungan hidup setiap mahluk dari masa ke masa, meliputi atita (keadaan pada masa lampau), wartamana (keadaan pada masa sekarang), dan nagata (keadaan pada masa yang akan datang). Kehidupan tokoh/pelaku yang diterima selalu berhubungan dengan karma yang dilakukan pada kehidupan yang lain. Baik buruk perbuatan yang pernah dilakukan pada kehidupan masa lampau akan mempengaruhi peruntungan pada kehidupan sekarang, begitu serusnya. Lingkaran karma bergerak tanpa henti sebagai wasana (bekas/sisa) yang dinikmati dan mempengaruhi kehidupan pada masa yang lain. Demikian pula yang terjadi dalam kelahiran Bhisma, ia diikat oleh karmanya sendiri pada masa sebelumnya.

Bhisma adalah jelmaan sang Prabhata salah satu dari delapan basu yang disebut Astabasu. Karena cintanya terhadap istri, ia berusaha memenuhi keinginannya mencuri lembu Nandini milik bagawan Wasistha sebagaimana dalam kutipan berikut:

...,sangke sih sira mapriya, lumampah ta sang Prabhata sumyang iwwang sanaknya kabeh, inalap nira tang Nandini. Wruh pwa bhagawan Wasista, sinapa nira sang Astabasu, mangjanma ring manusa, apan tan solah ning dewata solah nira,... (Adiparwa, XII. 18). 
Terjemahan:

...,Karena cintanya kepada istri, sang Prabhata memanggil saudaranya yang lain, dicuri/ diambilnya lembu Nandini. Bagawan Wasistha mengetahu hal itu, maka dikutuknya sang Astabasu, agar menjelma menjadi manusia, karena perbuatan yang dilakukan bukan perbuatan dewa lagi,...

Kutipan di atas menjelaskan bahwa sang Prabhata adalah anggota kerabat dewa yang menempati kahyangan. Kahyangan adalah wilayah transendental tempat para dewa bersemayam dan melakukan hal-hal kebaikan. Sifat dan laku dewa adalah refleksi manusia yang dijadikan panutan tentang kemuliaan, meskipun prilaku dewa tidak bisa disamakan dengan prilaku yang dimiliki manusia. Kejujuran, murah hati dan keluhuran budi dianggap sifat-sifat kedewaan yang dijadikan acuan bagi manusia. Sebaliknya kedurhakaan, kedengkian, kebohongan dan sifat-sifat buruk lainnya adalah sifat keraksasaan yang dihinakan oleh manusia. Sifat inilah yang dilanggar oleh Prabhata, didorong oleh rasa cinta yang amat besar kepada istri, ia menyalahi norma-norma kedewataan yang menyebabkan ia bersama basu lainnya dikutuk oleh bagawan Wasistha hingga menjalani kehidupan di dunia ini. Prabhata menjalani hukuman kutuk yang lebih berat karena menjadi pemimpin atau pelaku utama pencurian lembu Nandini milik bagawan Wasistha.

Hal yang sama tejadi pada diri raja Santanu yang amat tertarik dengan kemolekan Jahnawi (dewi Gangga), sehingga menurut begitu saja terhadap permintaan Dewi Gangga. Ia bersedia menjadi istri Santanu dengan syarat suaminya tidak boleh mengeluh apapun yang dilakukannya. Akhirnya tujuh anak keturunan Santanu dengan dewi Gangga dibuang ke sungai oleh istrinya. Raja Sentanu tidak berani melakukan protes karena perjanjian dan rasa cinta yang mendalam pada istrinya, seperti kutipan berikut.

..., Sang Gangga! Akweh dahat anakta, timibaken ing lwah juga kabeh. Mahapapa temen prawrttinta. Tuhuwusa nika ulahta, mamati rare!. Mangkana ling maharaja Santanu (Adiparwa, XII. 18)

Terjemahan:

..., Sang Gang putramu banyak sekali, tetapi kau lempar semua ke dalam. Perbuatanmu itu sangat terkutuk/jahat. Hentikanlah perbuatanmu membunuh anak!. Demikian tegur maharaja Santanu.

Kutipan di atas menjelaskan bahwa cinta dan janji Santanu pada dewi Gangga istrinya membuatnya ia tidak punya alasan untuk menegur istrinya yang telah membuang tujuh anaknya ke sungai. Baru setelah anak ke delapan lahir ia memberanikan diri menegur istrinya yang membuat ia harus ditinggal istri yang dicintainya, karena Santanu telah melanggar perjanjian yang disepakatinya.

Pada bagian lain Bhisma yang lahir sebagai anak ke delapan melakukan sumpah brahmacari. Sumpah brahmacari Bhisma juga merupakan bagian kutuk bagawan Wasistha, sebagaimana tersurat dalam kutipan berikut.

...,Tatan pastri dlaha magehakna dharma sang watek Kuru, gumawakna sakahyun sang bapa”. Mangkana ling sang Wasistha,... (Adiparwa, XII. 19)

Terjemahan:

...,Kelak tidak akan beristri, ia akan mempertahankan dharma/kewajibannya saja bagi keturunan Kuru, dan menuruti keinginan ayahnya. Demikian kutuk sang Wasistha,...

Kutipan di atas menegaskan bahwa Bhisma, selain mendapat kutukan lebih berat dengan lebih lama hidup di dunia, hidupnya juga dibelenggu oleh kewajiban dirinya terhadap keturunan Kuru dan ayahnya. Inilah yang membuat Bhisma tidak bisa lepas dari ikatan dharma/kewajibannya untuk tetap menjaga bangsa Kuru atau negeri Astinapura. Kesetiaan Bhisma terhadap Hastinapura dibuktikan oleh dirinya yang membela serta memihak Kaurawa ketika perang Bharatayuda terjadi. Bagi Bhisma bukan berpihak pada Pandawa atau 
Kaurawa yang terpenting melakukan tugas dan kewajibannya mempertahankan serta membela negerinya Hastinapura. Hari kematiannya juga ditentukannya sendiri karena ia merasa sudah tidak mampu lagi menjaga negeri Hastinapura kesayangannya, dan kewajibannya sudah dianggap selesai.

Demikian juga dengan sumpah Bhisma untuk melakukan brahmacari adalah bagian dari kutuk yang diterimanya dan dijalaninya di dunia ini. Ia melucuti kebahagiaan dengan mengorbankan hak dirinya untuk menggantikan tahta ayahnya yang seharusnya ia dapatkan semata-mata demi kebahagiaan ayahnya.

\subsection{Dewi Gangga Pembuang Anak Kandung}

Bagi seorang ibu anak adalah mutiara yang menjadi kebanggaan di dalam hidupnya. Kepada anak seorang ibu menumpahkan dan mencurahkan kasih sayang. Anak adalah buah hati yang membuat hidup seorang ibu menjadi lebih bermakna. Hal ini adalah prilaku normatif seorang ibu atau orang tua yang dilakukan terhadap anaknya. Tetapi perlakuan dewi Gangga yang membuang anak kandungnya justru tidak lazim dilakukan oleh seorang ibu, apapun alasannya. Suaminya Santanu tidak berani menegur tindakan istrinya karena ia telah terikat janji saat sebelum pernikahan terjadi untuk tidak melarang apapun yang dilakukan istrinya,seperti kutipan berikut.

“...,Kuneng samayangku lawan kita, haywa ta nghulun wineh ujar tanyogya mwang tan uhutaneng sarwakarya. Yapwan sinengkeran ing sabda tan pamit sakahyune ne nghulun, niyata tinggalaknangku kita".

Terjemahan:

“...,Adapaun perjanjian perjanjian saya dengan maharaja, janganlah saya sampai mendengar kata yang tidak senonoh, jangan pula menghalang-halangi perbuatan saya. Kalau dirintangi, dengan kata yang tidak yang tidak menurut kemauan saya, maharaja saya akan tingalkan".

Hal inilah yang membuat Santanu tidak berani menegur dan melarang istrinya membuang bayinya karena ia sangat mencintai istrinya, takut ditinggal pergi. Alasan dewi Gangga tega membuang anaknya hanya karena ia telah berjanji pada kehidupan sebelumnya untuk membantu Astabasu agar segera kembali ke asalnya.

Dari kaca mata duniawi dewi Gangga dianggap merusak nilai-nilai kemanusiaan karena tega membuang anak kandung yang masih bayi ke tengah sungai. Anak yang justru tidak memiliki dosa apapun di dunia ini dibuang oleh ibu kandungnya sendiri. Tidak ada alasan yang membenarkan seorang ibu melakukan kejahatan dengan membuang bayinya yang baru lahir ke tengah sungai.

Tidak mudah menerima perbuatan biadab seperti yang dilakukan dewi Gangga ini. Tetapi dari kaca mata lain dewi Gangga dianggap melakukan perbuatan mulia yang telah menyelamatkan atau membantu Astabasu untuk segera kembali ke tempat asalnya, sebagaimana perjanjian sebelum dewi Gangga menjelma ke dunia ini. Dewi Gangga adalah titisan dewa yang melakukan tindakan di dunia ini berdasarkan pesan atau keterikatan yang dibawa semasa kehidupannya terdahulu di dunia asalnya.

Dewi Gangga membuang anaknya di tengah sungai karena keterikatannya dengan janji dirinya sebelum menitis ke dunia untuk segera mengembalikan Astabasu kembali ke asalnya. Apa yang dilakukan dewi Gangga di dunia ini adalah menjalankan hutang (rna) untuk memenuhi janji sebelum penjelmaannya ke dunia. Inilah dharma bagi titisan dewa untuk melakukan sesuatu berdasarkan titipan pada kehidupan sebelumnya yang tidak bisa diingkari. Apabila dewi Gangga tidak membuang tujuh bayi anak kandungnya ia bahkan dianggap ingkar janji (long semaya) terhadap Astabasu.

Anak ke delapan dewi Gangga adalah anak yang telah ditentukan lebih lama hidup di dunia. Anak yang juga dapat menghapus kekecewaan Santanu suaminya. Raja Santanu menerima kelahiran anak ke delapan dan memaafkan kesalahan istrinya, setelah ia tahu bahwa dewi Gangga hanyalah sebagai perantara membantu Astabasu untuk cepat kembali ke asalnya. 


\section{SIMPULAN}

Cerita kutuk Astabasu diawali oleh kelakuan Prabhata (salah satu dari Astabasu) yang berupaya memenuhi keinginan istrinya sang Dyoh untuk mencuri sapi Nandini milik bagawan Wasistha. Memenuhi hasrat istri tanpa pertimbangan akal justru menjadi petaka karena Prabhata dan Astabasu lainnya dikutuk oleh bagawan Wasistha. Begitu pula keadaan yang menimpa maharaja Santanu, ia hanya bisa membisu ketika istrinya dewi Gangga membuang tujuh anak kandungnya, karena sebelumnya telah terikat janji untuk tidak melarang apapun yang diperbuat istrinya. Cerita ini memberi pesan bahwa cinta kasih suami terhadap istri tanpa dilandasi oleh batas pertimbangan logika justru menunai petaka.

\section{DAFTAR PUSTAKA}

Fashri, Fauzi. 2007. Penyingkapan Kuasa Simbol, Apropriasi Reflektif Pemikiran Pierre Bourdieu. Yogyakarta: Juxtapose.

Pendit, Nyoman S. 1980. Mahabharata Sebiah Perang Dasyat Medan Kurukshetra. Jakarta: Bharata Karya Aksara.

Ratna, Nyoman Kuta. 2006. Teori, Metode, dan Teknik Penelitian Sastra. Yogyakarta: Pustaka Pelajar.

Ricoeur, Paul. 2006. Hermeneutika Ilmu Sosial. Yogyakarta: Kreasi Wacana

Widia, IGusti Made (penerjemah). 1994.Adiparwa. Denpasar: CV Kayumas.

Widyatmanta, Siman. 1958. Adiparwa, Urusan Adat-Istiadat \& Ceritera Rakyat Djawatan Kebudajaan Dep. P.D. \& K. Tjabang Bagian Bahasa: Jogjakarta 